\title{
LATE RESULTS OF CATHETER-DIRECTED RECOMBINANT TISSUE PLASMINOGEN ACTIVATOR FIBRINOLYTIC THERAPY OF ILIOFEMORAL DEEP VENOUS THROMBOSIS
}

Ivan Benaduce Casella, Calógero Presti, Ricardo Aun, Joseph Elias Benabou, Pedro Puech-Leão

Casella IB, Presti C, Aun R, Benabou JE, Puech-Leão P. Late results of catheter-directed recombinant tissue plasminogen activator fibrinolytic therapy of iliofemoral deep venous thrombosis. Clinics. 2007;62(1):31-40.

PURPOSE: To evaluate the efficacy of catheter-directed low-dose recombinant tissue-type plasminogen activator infusion in the treatment of iliofemoral deep venous thrombosis and prevention of post-thrombotic syndrome.

METHOD: Eighteen patients (out of 260 evaluated) with acute iliofemoral deep venous thrombosis and no previous evidence of venous insufficiency were prospectively selected for thrombolytic therapy. Catheter-directed low-dose recombinant tissue-type plasminogen activator $(1 \mathrm{mg} / \mathrm{h})$ was infused into the thrombotic segments.

RESULTS: Effective fibrinolysis was achieved in 14 of 18 cases, with correlation between effective fibrinolysis and major/ complete resolution of acute signs and symptoms $(P<.01)$. There were no episodes of major complications. Four patients presented with early rethrombosis ( 1 to 8 weeks). Individuals were followed for a period up to 131 weeks (average, 85.2). The incidence of clinical signs and symptoms of venous insufficiency and duplex-scan findings of valvular reflux was significantly lower in the patients in which lytic therapy succeeded and patency was kept, compared with patients experiencing acute therapeutic failure or rethrombosis $(P<.01)$.

CONCLUSIONS: Low-dose recombinant tissue-type plasminogen activator fibrinolytic therapy is safe and effective in the treatment of acute iliofemoral venous thrombosis. The late evolution as revealed clinically and by ultrasound was superior in patients for whom lytic therapy was effective.

KEYWORDS: Deep venous thrombosis. Fibrinolysis. rt-PA. Post-thrombotic syndrome. Venous insufficiency.

\section{INTRODUCTION}

Deep venous thrombosis (DVT) of the lower limbs can lead to functional and anatomic venous alterations that characterize post-thrombotic syndrome. Although the determinant factors that result in chronic venous insufficiency after a DVT episode are not completely understood, there

Division of Vascular Surgery, São Paulo University Medical School - São Paulo/SP, Brazil.

Division of Radiology, São Paulo University Medical School - São Paulo/SP, Brazil.

Email: ivancasel@uol.com.br

Received for publication on June 20, 2006.

Accepted for publication on October 09, 2006. appears to be a strong correlation between post-thrombotic syndrome and the extent of the thrombotic process. The progress of distal DVTs is usually benign, ${ }^{1,2}$ with a high rate of recanalization and a low rate of venous reflux. On the other hand, the persistence of chronic occlusions and venous reflux is common in extensive DVTs. ${ }^{3,4}$ Up to $96 \%$ of patients with proximal DVT may progress with reflux and/or venous obstruction. ${ }^{5}$ It should also be noted that venous segments with evidence of reflux after DVT recanalization were those presenting a spontaneous fibrinolysis up to 7 times longer than the observed in competent segments, suggesting that thrombus removal time is also an important factor in vein valve preservation. ${ }^{6}$ 
The use of locally infused fibrinolytic agents presents the possibility of direct intervention for massive and immediate thrombus removal..$^{7-14}$ Theoretically, this specific feature of thrombolysis should lead to immediate improvement of clinical results in extensive cases of DVT, as well as to preservation of valvular competence and venous wall morphology as has been described by experimental studies. ${ }^{15,16}$

The purpose of this study was to evaluate the late results of low-dose of recombinant tissue-type plasminogen activator (rt-PA) catheter-directed thrombolysis in proximal DVT, studying the effectiveness of fibrinolysis in prevention of late clinical and echographic sequelae characteristic of post-thrombotic syndrome.

\section{METHOD}

In a prospective study between June 2001 and January 2005, 260 patients with clinical and duplex-scan diagnosis of acute lower limb DVT were evaluated. The inclusion criterion for thrombolytic therapy was the presence of acute unilateral iliofemoral DVT (up to 14 days) without any history or diagnostic evidence of previous episodes of DVT or venous insufficiency of the affected limb.

Patients with the described characteristics were excluded if any of the following features were present: contraindications to the use of thrombolytic agents, such as history of major bleeding; recent delivery or major surgery (up to 10 days); neurosurgical intervention (up to 3 months); and recent significant trauma or disease with known risk of hemorrhagic complications. Patients with renal failure or previous history of allergic reaction to iodine contrast were also excluded. The age limit for thrombolysis was arbitrarily set at 70 years. Inclusion was conditional to the signature of the informed consent agreement. This clinical research project was approved by the Institutional Committee of Ethics in Research. In adherence to the above criteria, 18 of the examined subjects fulfilled the selective criteria for thrombolysis therapy and were included.

Access to the deep venous system was obtained through surgical dissection of the retromalleolar ipsilateral lesser saphenous vein (LSV) in 11 cases and of the proximal lesser saphenous vein just below the genicular fold in 4 cases. The dissection site was defined by previous duplex scan image. Dissection of distal posterior tibial vein was performed in 1 patient in which the lesser saphenous vein was considered inadequate. The technique of popliteal vein puncture with ultrasound guidance became accessible during this study and was performed in 2 patients.

After insertion of a $5 \mathrm{~F}$ sheath, a multiple-side-hole $5 \mathrm{~F}$ catheter was positioned under radioscopic viewing in the iliofemoral thrombotic segments, and it was eventually repositioned to a distal position during therapy. In the 2 later cases, a coaxial infusion system consisting of a Katzen infusion wire (Boston Scientifics, USA) inserted through the catheter was used.

Initial prethrombolysis phlebographic images were taken to assess the extent of the thrombotic process, using $30 \mathrm{~mL}$ of iodinated contrast infused through the sheath and/ or the catheter.

The patients were then sent to the semi-intensive care unit, and infusion of the rt-PA ("Actilyse", Boehringer Ingelheim, Germany) was initiated at a constant dose of 1 $\mathrm{mg} / \mathrm{h}$ diluted in $0.9 \%$ saline, without bolus. Dilution of the drug varied from patient to patient, ranging from 0.025 to $0.1 \mathrm{mg} / \mathrm{mL}$ during the study. In case of coaxial infusion, the lytic solution was divided for the two devices. Unfractionated heparin was utilized as an adjuvant drug, administered by systemic infusion at an initial dose of $12,000 \mathrm{IU} /$ day, and then adjusted to maintain a partial thromboplastin time of close to 60 seconds.

Patients were continuously monitored to detect clinical sings and symptoms of complications such as pulmonary embolism or hemorrhages. Blood samples were taken every 12 hours for hematocrit, hemoglobin, partial thromboplastin time, fibrinogen, and platelet count to adjust the heparin dose and detect blood loss.

Control phlebographies were performed every 12 to 15 hours. The initial and control phlebographies were submitted to a quantitative thrombus volume estimation as described by Marder et $\mathrm{al}^{17}$ and modified by the authors, employing some of the parameters proposed by the Committee for International Standards of Chronic Venous Diseases ${ }^{18}$ (Figure 1). The differences in the phlebography values were used to estimate the percentage of thrombolysis, and a 50\% to $100 \%$ removal of the thrombus was considered to be technically satisfactory.?

Venous segments assessed: Common iliac, external iliac, common femoral, proximal and distal superficial femoral ${ }^{*}$ and popliteal vein.

Phlebographic scoring of venous thrombosis: Complete occlusion - 3; Segmental occlusion - 2; Non-occlusive parietal thrombosis -1 ; Absence of thrombi -0 .

Total score calculated by the sum of each segment score. Final score calculated by percentual difference between pre and post-thrombolysis phlebographies

*The presence of a second superficial femoral vein should be considered.

Figure 1 - Measurement of thrombotic volume of venous segments 


\section{Postfibrinolysis procedure}

Infusion of rt-PA was interrupted in case of significant bleeding, fibrinogen levels below $100 \mathrm{mg} / \mathrm{dL}$, or absence of radiological improvement in 2 consecutive phlebograms. At the end of the procedure, independently of thrombolytic success, a therapeutic dose of continuous intravenous unfractionated heparin treatment was initiated $(20 \mathrm{IU} / \mathrm{K} /$ h), followed by oral anticoagulation with warfarin. Adjuvant elastic compression therapy was recommended and encouraged. After hospital discharge, the patients were followed weekly in the outpatient clinic during the first month and at monthly intervals thereafter. During follow-up, patients underwent multiple duplex scan examinations of the deep venous system of the affected lower limb. The scope of this procedure was to confirm patency of the deep venous system, presence of residual thrombi in the segments treated and in the infragenicular veins, and the presence of venous reflux. Generally, duplex-scan exams were performed at an early stage (up to 3 months postdischarge), during an intermediate stage, and at the end of the outpatient followup by the same qualified examiner using a HDI $5000 \mathrm{Du}-$ plex ultrasound system (Advanced Technology Laboratories, Bothell, WA, USA). Valvular reflux was confirmed by the echographic technique described by Masuda et al. ${ }^{19}$ Reflux was assessed only in patent venous segments, since residual thrombi can provoke temporary reflux that can eventually disappear after recanalization. The venous segments studied included common iliac, external iliac, common femoral, deep femoral, superficial femoral, popliteal, anterior and posterior tibial veins, and the lesser saphen- ous vein, the latter only when used as a vascular access.

At the end of the clinical follow-up, the subjects were classified according to degree of clinical sequelae based on volume of residual edema, signs of exacerbation of superficial venous circulation, intensity of pain or discomfort, and subjective perception of life quality preservation.

In the statistical analysis, the Spearman's test was used to compare 2 quantitative variables. The Mann-Whitney's "U" test compared the quantitative data between 2 groups. Binary or dichotomized data were compared with $2 \times 2$ tables and submitted to the Fisher's exact test. $P$ values of less than 0.05 were considered significant.

\section{RESULTS}

The clinical onset of the DVT ranged from 2 to 14 days (7.2 \pm 4.2 days). The chief characteristics and immediate results of this therapy are summarized in Table 1 . The percentage of thrombus removal ranged from $11 \%$ to $100 \%$ (mean/SD, $68.3 \% \pm 25.2 \%$ ). The percentage of thrombolysis in 14 subjects was greater than $50 \%$ of the supragenicular thrombotic volume. Significant or complete clinical improvement occurred in 12 of the 18 individuals. A statistically significant correlation was found between the percentage of thrombus removal and degree of clinical improvement $(P<0.01$, Table 2$)$.

The duration of the rt-PA infusion ranged from 12 to 74 hours $(42.1 \pm 16.8$ hours $)$, and the total dose used was 12 to $72 \mathrm{mg}(39.7 \pm 16.1 \mathrm{mg})$. No correlations were noted between the dilution, dose or duration of the rt-PA infu-

Table 1 - Clinical characteristics and initial results of thrombolysis

\begin{tabular}{|c|c|c|c|c|c|c|c|c|}
\hline & Age,Gender & Limb & $\begin{array}{c}\text { Onset of } \\
\text { symptoms (days) }\end{array}$ & $\begin{array}{c}\% \text { of throm- } \\
\text { bolysis }\end{array}$ & $\begin{array}{c}\text { Clinical } \\
\text { Improvement }\end{array}$ & $\begin{array}{l}\text { Time/h } \\
\text { Infusion }\end{array}$ & $\begin{array}{c}\text { Venous stenosis } \\
\text { or occlusion }\end{array}$ & Complications \\
\hline 1 & $54, \mathrm{M}$ & $\mathrm{L}$ & 14 & 89 & ++ & 42 & & \\
\hline 2 & $56, \mathrm{M}$ & $\mathrm{L}$ & 7 & 83 & +++ & 15 & & \\
\hline 3 & $17, \mathrm{~F}$ & $\mathrm{R}$ & 3 & 33 & + & 36 & & \\
\hline 4 & $19, \mathrm{~F}$ & $\mathrm{R}$ & 4 & 39 & + & 56 & & \\
\hline 5 & $63, \mathrm{~F}$ & $\mathrm{R}$ & 12 & 11 & - & 12 & & \\
\hline 6 & $33, \mathrm{M}$ & $\mathrm{L}$ & 3 & 93 & ++ & 32 & CIV & hematoma \\
\hline 7 & $20, \mathrm{~F}$ & $\mathrm{~L}$ & 4 & 83 & +++ & 56 & & \\
\hline 8 & $33, \mathrm{~F}$ & $\mathrm{~L}$ & 4 & 100 & ++ & 60 & CIV & \\
\hline 9 & $42, F$ & $\mathrm{~L}$ & 14 & 63 & ++ & 43 & & hematuria \\
\hline 10 & $24, F$ & $\mathrm{~L}$ & 3 & 59 & +++ & 57 & & \\
\hline 11 & $41, \mathrm{M}$ & $\mathrm{L}$ & 9 & 81 & ++ & 29 & & \\
\hline 12 & $30, \mathrm{~F}$ & $\mathrm{~L}$ & 9 & 58 & + & 59 & & \\
\hline 13 & $46, F$ & $\mathrm{R}$ & 10 & 56 & ++ & 33 & & \\
\hline 14 & $21, \mathrm{~F}$ & $\mathrm{~L}$ & 12 & 63 & + & 45 & & \\
\hline 15 & $56, \mathrm{~F}$ & $\mathrm{~L}$ & 12 & 71 & ++ & 42 & & \\
\hline 16 & $18, \mathrm{~F}$ & $\mathrm{~L}$ & 2 & 48 & + & 20 & & low fibrinogen \\
\hline 17 & $17, \mathrm{~F}$ & $\mathrm{R}$ & 5 & 100 & +++ & 74 & IVC & \\
\hline 18 & $58, \mathrm{~F}$ & $\mathrm{~L}$ & 4 & 100 & +++ & 48 & CIV & \\
\hline
\end{tabular}

$\mathrm{F}=$ female $; \mathrm{M}=$ male $; \mathrm{L}=$ left $\mathrm{R}=$ right $;(-)=$ absent,$(+)=$ poor,$(++)=$ significant, $(+++)=$ complete $; \mathrm{CIV}=$ common iliac vein; IVC = inferior vena cava 
Table 2 - Mean percentage thrombolysis vs acute clinical improvement

\begin{tabular}{llll}
\hline $\begin{array}{l}\text { Clinical } \\
\text { response }\end{array}$ & $\begin{array}{l}\text { Number of } \\
\text { cases }\end{array}$ & $\begin{array}{l}\text { Average thrombus } \\
\text { removal }(\%)\end{array}$ & $\begin{array}{l}\text { Range of thrombus } \\
\text { removal }(\%)\end{array}$ \\
\hline Absent & 01 & 11 & 11 \\
Poor & 05 & 48.2 & $33-63$ \\
Significant & 07 & 79 & $56-100$ \\
Complete & 05 & 85 & $59-100$ \\
\hline
\end{tabular}

Spearman's $R=0.723(P<0.01)$.

sion and the percentage of lysis or clinical improvement. No correlation was established between clinical onset of disease and acute clinical results $(P=0.59)$, total dose of rt-PA $(P=0.69)$, or percentage of lysis $(P=0.98)$.

\section{Complications, concomitant venous stenosis, and early rethrombosis}

Bleeding at the catheter insertion site occurred only in cases of lesser saphenous vein dissection, 3 in the retromalleolar region, and 1 in the knee fold. It was controlled in all cases by simple elevation of the limb and application of a compressive bandage, without requiring transfusion or interruption of the procedure. Patient \#09 displayed gross hematuria after 40 hours on rt-PA, with spontaneous remission after interruption of lysis. At the end of the thrombolysis, patient \#06 demonstrated an extensive hematoma of the left upper limb related to accidental puncture of the deep vein for collection of a blood sample.

Patient \#16 presented with low serum fibrinogen levels $(<80 \mathrm{mg} / \mathrm{dL})$ during the first hours of rt-PA infusion, and lysis was interrupted in spite of the absence of clinical or laboratorial sign of blood loss.

After complete lysis of acute thrombi, patient \#17 was diagnosed with chronic caval obstruction with partial recanalization. A large and somewhat effective collateral venous circulation through paravertebral veins and azygos system was observed, and no interventional therapy was attempted.

Left-sided common iliac vein stenosis was unmasked after lysis in 3 patients. One underwent venous stenting (14 x $60 \mathrm{~mm}$ Wallstent) with technical success and a 12-week follow-up patency. One refused to undergo angioplasty and the other developed early rethrombosis (4 days after lysis) before stenting.

Three other patients developed early rethrombosis, all by 8 weeks after lytic therapy. No association was observed between the episodes of rethrombosis and specific characteristics, such as degree of lysis, side of the disease, associate venous lesions, or others.

\section{Late Results}

Patients were divided in 2 groups according with the final patency results as follows: individuals with initial lytic failure or rethrombosis and individuals who presented effective thrombolysis and continued patency in terms of clinical and duplex-scan late findings. Individual late results are summarized in Table 3. Apart from these different outcomes, no other variable tested revealed any divergence between the two groups. The mean clinical and echographic follow-up periods were greater than 1 year and are statistically similar between the groups (Table 4). In

Table 3 - Late clinical and echographic results of thrombolysis therapy

\begin{tabular}{lllll}
\hline No. & Result & $\begin{array}{l}\text { Severe } \\
\text { Clinical } \\
\text { Sequelae }\end{array}$ & $\begin{array}{l}\text { Valve } \\
\text { Reflux }\end{array}$ & $\begin{array}{l}\text { Chronic } \\
\text { Occlusions }\end{array}$ \\
& & - & - & - \\
\hline 1 & Patency & - & - & - \\
2 & Patency & + & - \\
3 & Initial Failure & + & + & + \\
4 & Initial Failure & + & + & + \\
5 & Initial Failure & + & + & - \\
6 & Rethrombosis & + & + & - \\
7 & Patency & + & - & - \\
8 & Patency & - & - & - \\
9 & Patency & - & - & - \\
10 & Patency & - & + & + \\
11 & Rethrombosis & + & + & - \\
12 & Rethrombosis & + & - & - \\
13 & Patency & - & + & + \\
14 & Rethrombosis & + & - & - \\
15 & Patency & + & + & + \\
16 & Failure & + & - & - \\
17 & Patency & - & - & - \\
18 & Patency & - & & \\
\hline
\end{tabular}

(+) present (-) absent

Table 4 - Period of clinical and duplex-scan follow-up (weeks)

\begin{tabular}{lll}
\hline & Clinical & Duplex-scan \\
\hline General & $85.2 \pm 39.7(12-131)$ & $67.2 \pm 32.7(12-115)$ \\
Continued patency group & $77.4 \pm 41.3(12-131)$ & $59.8 \pm 31.2(12-99)$ \\
Initial failure / rethrombosis group & $95.1 \pm 37.8(44-130)$ & $76.4 \pm 34.0(44-115)$ \\
$P$ & $0.46^{*}$ & $0.23^{*}$ \\
\hline
\end{tabular}

Mean, standard deviation and minimum/ maximum values. *Mann-Whitney's "U" test. Nonsignificant values. 
Table 5 - Late results of patients showing venous patency or failure/rethrombosis

\begin{tabular}{llll}
\hline & Continued patency group & Initial failure / rethrombosis group & $P($ Fisher test) \\
\hline Supragenicular chronic occlusions & $0 / 10$ & $5 / 8$ & $<0.01$ \\
Infragenicular chronic occlusions & $0 / 10$ & $2 / 8$ & $\mathrm{NS}$ \\
Supragenicular valvular reflux & $1 / 10$ & $8 / 8$ & $<0.01$ \\
Infragenicular valvular reflux & $1 / 10$ & $6 / 8$ & $<0.05$ \\
Significant clinical symptoms & $2 / 10$ & $8 / 8$ & $<0.01$ \\
\hline
\end{tabular}

Table 6 - Association between the degree of late clinical signs and symptoms of PTS and final duplex-scan pathologic findings

\begin{tabular}{lccc}
\hline & \multicolumn{2}{c}{ Intensity of clinical signs and symptoms } & \\
& Moderate / severe & Absent / light & $P$ (Fisher test) \\
\hline Supragenicular chronic occlusions & $5 / 10$ & $0 / 8$ & $<0.05$ \\
Infragenicular chronic occlusions & $2 / 10$ & $0 / 8$ & NS \\
Supragenicular valvular reflux & $9 / 10$ & $0 / 8$ & $<0.01$ \\
Infragenicular valvular reflux & $7 / 10$ & $0 / 8$ & $<0.01$ \\
\hline
\end{tabular}

PTS = post-thrombotic syndrome

the 4 patients who presented rethrombosis, the initiation of the follow-up period was established as beginning from the new thrombotic episode.

The individuals with initial lytic failure or early rethrombosis had a significantly higher incidence of severe clinical signs and symptoms of post-thrombotic syndrome. as well as venous reflux and chronic occlusions, compared with those with long-time patency (Table 5). Also, patients with preserved valve function displayed a lower incidence of severe clinical sequelae, as did patients with complete supragenicular recanalization (Table 6). Although no direct fibrinolytic infusion was performed in the infragenicular veins, a lower incidence of venous reflux in such segments was also noted in patients of the long-time patency group.

None of the patients studied displayed clinical signs of venous insufficiency of the lesser saphenous vein (when used as access site) such as venous stasis or varicose branches. Nevertheless, late control duplex-scans showed evidence of 4 cases of reflux and 1 of occlusion of the lesser saphenous vein. Significant correlations between these lesser saphenous vein alterations and immediate or late results were not observed. The small series made a proper comparison of the different access techniques impossible.

\section{DISCUSSION}

Along with arterial occlusive disease ${ }^{20}$, post-thrombotic syndrome is one of the vascular diseases that most frequently lead to impaired quality-of-life.

Indication for lytic therapy for proximal DVT is still fraught with controversy. Systemic fibrinolysis which was tried in the past, with poor immediate results and an unacceptable incidence of complications, ${ }^{21}$ was soon abandoned. Current selective techniques of drug delivery have produced better results but are restricted to very few medical centers, most of them related to research activities. Possible reasons for the resistance in accepting the method are lack of appropriate material and human resources, poor experience on the part of the vascular surgeons with US-guided vascular access and fibrinolytic applications, and lack of solid scientific conclusions about the cost-benefit ratio of thrombolysis. Economical aspects are another restrictive point, even though the initial costs may be compensated by longterm reduction of post-thrombotic syndrome complications. ${ }^{22}$

Patients with extensive DVT treated by anticoagulants usually present fairly poor rates of spontaneous short-time recanalization. ${ }^{23-25}$ Catheter-directed venous lysis enables the changing of the natural history of venous thrombosis, promoting early removal of the thrombus and re-establishment of venous patency.

In this study, only $6.9 \%$ of the cases assessed were selected for thrombolytic therapy. This figure is fairly close to that reported by Markel et $\mathrm{al}^{26}$ and reflects the limited character of lysis as therapy for DVT. Also, the strict observation of the inclusion and exclusion criteria resulted in a small sample size that represents a limitation of the study. In spite of such limitations, we were able to identify shortand long-term results that, together with previous studies, help in understanding the role and limitations of fibrinolysis in DVT.

The main features of the dissection access of the lesser saphenous vein include the following: technical accessibil- 
ity; ease of accomplishment, elimination of the need for complex infra-structure, as in the case of guided puncture by echography; safety regarding puncture, because dissection is generally restricted to the superficial anatomic layers; and direct visualization of the lesser saphenous vein. Moreover, unlike popliteal vein puncture, the risk of accidental arterial puncture is eliminated.

In spite of the good results and the absence of major complications, dissection of the lesser saphenous vein has limitations, especially in its distal site. Primarily, the diameter of the vein may be inadequate for passage of the catheter, and anatomic variations or technical difficulties may prevent the catheter from reaching the deep venous system. The distal lesser saphenous vein may be unsuitable for introduction of large caliber devices, such as balloons and stents for angioplasty, to treat venous stenosis or spurs identified after lysis. This limitation is caused by the reduced distal diameter of this vein and the distance between the access site and the location of eventual lesions, eg, iliac stenosis in May-Turner syndrome. The solution to such a problem would be a second access through femoral vein puncture. In the 2 cases of US-guided popliteal puncture, there were no signs of hematoma or other complications. Iliac angioplasty and stenting was performed through this access without difficulty. In the authors' opinion, posterior tibial vein dissection is an option that should usually be avoided.

In this study, improvement of symptoms during the acute stage was significantly associated with success of the thrombolysis, pointing to a direct relationship between the volume of lysis and the degree of clinical improvement shown. This evidence suggests the efficacy of lytic therapy for alleviating exuberant symptoms related to extensive DVT. The rate of early recanalization found in this study is comparable to other series of lysis with other drugs or with larger doses of rt-PA.7,10,27

In most studies of venous lysis of the lower limbs, the selection of patients with acute DVT did not necessarily exclude those suffering from previous venous insufficiency. These studies focus their analysis on the immediate results of thrombolytic treatment. However, the diversity of their groups makes it difficult to identify the eventual benefits of lysis on the clinical outcome of patients. In our study, we excluded those subjects who displayed any evidence of DVT or chronic venous insufficiency prior to the acute episode. Therefore, it was reasonable for us to conclude that the presence of residual thrombosis and/or late valvular reflux in some patients was directly related to the studied DVT episode.

In the present series, there were no clinically identifiable episodes of pulmonary embolism. The combined use of thrombolytic infusion and lower doses of heparin that was controlled and adjusted by partial thromboplastin time seemed to create a state of systemic anticoagulation that was sufficient for preventing extension of the thrombotic process, as observed on the control phlebograms.

Bleeding at the catheter insertion site is a frequent complication and to a certain extent predictable in arterial and venous thrombolytic therapy. ${ }^{28}$ In this study, 4 of the 18 patients developed bleeding from the insertion site. For all 4 patients, local pressure bandages and elevation of the limb were enough to stop or substantially reduce bleeding, without requiring interruption of therapy. This observation is a point in favor of the safety of this lesser saphenous vein dissection approach combined with the use of low doses of rt-PA.

Only 1 patient exhibited spontaneous bleeding, characterized by gross hematuria, which is comparable to reports of many other series. Although 1 patient developed bleeding with hematoma in the upper limb, this was not a spontaneous event, but was more of a iatrogenic outcome due to many attempts to obtain a blood sample in a deep layer. This complication can be prevented by simple standardization of assay procedures such as specific orientation to avoid deep vein or arterial punctures and preparation of venous access for blood collection before starting fibrinolysis. No patient in the study presented systemic bleeding with hemodynamic instability or requiring transfusion, nor were there episodes of intracranial hemorrhage or deaths in the acute stage.

The mean clinical follow-up time was 85 weeks. Although this time is insufficient to observe late changes related to post-thrombotic syndrome such as cutaneous hyperpigmentation and phlebopathic ulcers, we believe it is adequate to assess early signs of venous insufficiency, such as discomfort, pain, and persistent edema.

Follow-up time was sufficient to obtain conclusive results regarding venous reflux by duplex scanning. Development of reflux after DVT is usually an early manifestation. However, this can be a temporary ${ }^{6}$ alteration caused by the presence of thrombi next to the valve cusps. Once the thrombi are removed by the endogenous lysis, the valvular segments could eventually become competent again. Average echographic follow-up time in this series was about 67 weeks, time enough for 13 patients to attain total recanalization and the remaining 5 to reveal patent venous segments capable of echographic evaluation for the presence of reflux. These facts underscore the validity of the results and minimize the risk of an incorrect evaluation, wich might follow the interpretion of fortuitous findings of transitory reflux as definitive consequences of the procedure. 
Preservation of patency obtained with rt-PA depends on various factors, some of which are difficult to determine and control, such as the presence of thrombophilias. Patient adherence to the anticoagulation program is also a decisive factor. In this investigation, lack of patient commitment to warfarin therapy and control was responsible for at least 2 cases of rethrombosis.

Although this was a prospective investigation, there was never an attempt to create an initial control group with conventional anticoagulation therapy. The main reason for this decision was the restrictive criteria of patient selection, which resulted in a small number of cases. A correct control group would have to be formed from a randomization of patients with the same clinical characteristics, resulting in the need of doubling the number of cases, making the study not feasible for a single-center investigation. Alternative nonrandomized control groups formed by patients with exclusion criteria would probably bring differences in the incidence and distribution of factors such as age, venous insufficiency, and other morbidities that would result in biases. For these reasons, this study and most of the similar investigations consist of a series of cases. Unintentionally, concerning the late results, the 8 patients with acute thrombolytic failure or early rethrombosis acted as a control group in comparison with the long-term effective thrombolysis group.

The difference in clinical and echographic outcome between the patients with long-term patency and those with initial lytic failure or early rethrombosis was clear, despite the small series. The outcome of the former was characterized by a lower incidence of clinical sequelae and venous reflux and complete recanalization of residual thrombi. On the other hand, only 3 of the 8 patients of the failure/rethrombosis group displayed complete recanalization, with the common presence of valvular insufficiency and late severe clinical symptoms. Even with partial recanalization, the patent segments of the patients in this group showed significant reflux.

Although infragenicular veins are not directly exposed to thrombolysis, data showed that patients with effective therapy had better results regarding valvular preservation than the others. One possibility is that massive supragenicular thrombotic removal may favor early recanalization of tibial and sural veins, with better chances of valve preservation.

The possibility that early venous thrombolysis could promote preservation of venous function has always been considered. However, only recently have studies been published mentioning midterm follow-up of subjects treated by fibrinolysis. AbuRhama et $\mathrm{al}^{29}$ studied patients with DVT divided into groups treated by lysis or conventional anticoagulation; they perceived greater persistence of clinical symptoms and valve reflux in the latter group. Elsharawyy and Elzayat ${ }^{30}$ observed patients treated by anticoagulation or lysis for 6 months after initial therapy and noted a lower incidence of reflux in the thrombolysis group. Nevertheless, the reports mentioned differ from this study in choice of lytic agent and dosage of rt-PA.

In most of the series reported, ${ }^{7,10,14,27}$ a significant percentage of patients underwent complementary procedures, notably angioplasties or venous stenting. But, although these procedures are associated to good technical success and patency over the midterm, ${ }^{31-33}$ there are no conclusive data regarding late outcome. In our series, 3 patients had venous stenosis with indication for angioplasty. Other residual occlusions were observed in sites not usually related to venous stenosis that later presented with spontaneous recanalization without clinical or echographic evidence of residual stenosis. It appears that despite segmental occlusions observed in some patients, a significant reduction of thrombotic volume may result in facilitation of the rapid removal of residual thrombi by the endogenous fibrinolytic system. In our series, $50 \%$ to $100 \%$ thrombus removal was achieved in an average of 42 hours, while Meissner et $\mathrm{al}^{34}$ reported a mean period of 3.4 months for endogenous removal of $50 \%$ of thrombi in lower limb DVT.

Less than half ( 8 of 18) of the treated patients showed good long-term clinical results. Although this observation may at first seem to discourage lytic therapy, further consideration reveals that it represents a huge improvement compared to classical anticoagulation therapy for extensive DVT, considering that benign evolution in such cases is rare. ${ }^{3-5}$

Comerota et $\mathrm{al}^{35}$ verified that subjects with DVT undergoing successful thrombolysis had a better life quality and lower incidence of post-thrombotic syndrome. symptoms than individuals treated only with anticoagulants. The present study compiled similar evidence, establishing a relationship between the effectiveness of the thrombolytic method and the favorable late clinical results, resulting in preservation of life quality in patients with successful therapy.

In conclusion, catheter-directed thrombolysis with low doses of rt-PA for treatment of acute DVT displayed good immediate success and absence of severe complications. In individuals in whom lysis was effective and the patency obtained was preserved, the incidence of late clinical and echographic alterations was notably minor. 


\section{RESUMO}

Casella IB, Presti C, Aun R, Benabou JE, Puech-Leão P. Resultados de longo prazo do tratamento fibrinolítico da trombose venosa iliacofemoral por infusão seletiva do ativador de plasminogênio tissular recombinante em baixas doses. Clinics. 2007;62(1):31-40.

OBJETIVOS: Avaliar a eficácia da infusão seletiva por cateter do ativador de plasminogênio tecidual recombinante em baixas doses no tratamento da trombose venosa iliacofemoral e na prevenção da síndrome pós-trombótica. MÉTODO: Dezoito pacientes (de 260 avaliados) portadores de trombose venosa profunda iliacofemoral sem evidência prévia de insuficiência venosa foram selecionados para terapia fibrinolítica e submetidos a infusão seletiva por cateter do ativador de plasminogênio tecidual recombinante na dose de $1 \mathrm{mg} / \mathrm{dl}$ nos segmentos venosos trombóticos.

RESULTADOS: Quatorze pacientes apresentaram fibrinólise efetiva; observamos correlação entre o grau de melhora clínica observado e a redução percentual do vo- lume trombótico $(\mathrm{P}<.01)$. Não houve episódios de complicações graves. Quatro pacientes apresentaram retrombose precoce (1 a 8 semanas). Os pacientes foram seguidos por um período de até 131 semanas (média 85.2). A incidência de sinais e sintomas clínicos de insuficiência venosa e os achados ecográficos de refluxo valvular foram significativamente menores nos pacientes em que a terapia fibrinolítica foi efetiva e a perviedade mantida ao longo do período de seguimento, na comparação com os casos de falha aguda ou de retrombose precoce $(P<.01)$.

CONCLUSÕES: A terapia fibrinolítica da trombose venosa iliacofemoral com ativador de plasminogênio tecidual recombinante seletivo em baixas doses demonstrou-se eficaz e segura. A evolução clínica e ecográfica tardia foi superior nos pacientes em que a terapia lítica foi efetiva.

UNITERMOS: Trombose venosa profunda. Ativadores do plasminogênio. Fibrinólise. Síndrome pós-flebítica. Insuficiência venosa.

\section{REFERENCES}

1. Masuda EM, Kessler DM, Kistner RL, Eklof B, Sato DT. The natural history of calf vein thrombosis: lysis of thrombi and development of reflux. J Vasc Surg. 1998;28:67-74.
2. McLafferty RB, Moneta GL, Passman MA, Brant BM, Taylor LM Jr, Porter JM. Late clinical and hemodynamic sequelae of isolated calf vein thrombosis. J Vasc Surg. 1998;27:50-7. 
3. O'Shaughnessy AM, FitzGerald DE. The patterns and distribution of residual abnormalities between the individual proximal venous segments after an acute deep vein thrombosis. J Vasc Surg. 2001;33:379-84.

4. Lindner DJ, Edwards JM, Phinney ES, Taylor LM Jr, Porter JM. Longterm hemodynamic and clinical sequelae of lower extremity deep vein thrombosis. J Vasc Surg. 1986;5:436-42.

5. Haenen JH, Janssen MC, van Langen H, van Asten WN, Wollersheim $\mathrm{H}$, Heystraten FM, et al. Duplex ultrasound in the hemodynamic evaluation of the late sequelae of deep venous thrombosis. J Vasc Surg. 1998;3:472-8

6. Meissner MH, Manzo RA, Bergelin RO, Markel A, Strandness DE Jr Deep venous insufficiency: The relationship between lysis and subsequent reflux. J Vasc Surg. 1993;18:596-608.

7. Mewissen MW, Seabrook GR, Meissner MH, Cynamon J, Labropoulos N, Haughton SH. Catheter-directed thrombolysis for lower extremity deep venous thrombosis: report of a national multicenter registry. Radiology. 1999;211:39-49.

8. Emanuelli G, Segramora V, Frigerio C. Selected strategies in venous thromboembolism: local thrombolytic treatment and caval filters. Haematologica. 1995;80 (2 Suppl):84-6.

9. Molina JE, Hunter DW, Yedlicka JW. Thrombolytic therapy for iliofemoral venous thrombosis. Vasc Surg. 1992;26:630-7.

10. Verhaeghe R, Stockx L, Lacroix H, Vermylen J, Baert AL. Catheter directed lysis of iliofemoral vein thrombosis with use of rt-PA. Eur Radiol. 1997;7:996-1001.

11. Palombo D, Porta C, Brustia P, Peinetti F, Udini M, Antico A, et al. La thrombolyse loco-régionale dans la thrombose veineuse profonde. Phlebologie. 1993;46:293-302.

12. Burkart DJ, Borsa JJ, Anthony JP, Thurlo SR. Thrombolysis of occluded peripheral arteries and veins with tenecteplase: a pilot study. J Vasc Interv Radiol. 2002;13:1099-102.

13. Sugimoto K, Hofmann LV, Razavi MK, Kee ST, Sze DY, Dake MD, et al. The safety, efficacy, and pharmacoeconomics of low-dose alteplase compared with urokinase for catheter-directed thrombolysis of arterial and venous occlusions. J Vasc Surg. 2003;37:512-7.

14. Shortell CK, Queiroz R, Johansson M, Waldman D, Illig KA, Ouriel K, et al. Safety and efficacy of limited-dose tissue plasminogen activator in acute vascular occlusion. J Vasc Surg. 2001;34:854-9.

15. Rhodes JM, Cho S-J, Gloviczki P, Mozes G, Rolle R, Miller VM. Thrombolysis for experimental deep venous thrombosis maintains valvular competence and vasoreactivity. J Vasc Surg. 2000;31:1193205 .

16. Cho JS, Martelli E, Mozes G, Miller VM, Gloviczki P. Effects of thrombolysis and venous thrombectomy on valvular competence, thrombogenicity, venous wall morphology, and function. J Vasc Surg. 1998;28:787-99.

17. Marder VJ, Soulen RL, Atichartakarn V, Budzynsky AZ, Parulekar S, Kim JR, et al. Quantitative venographic assessment of deep venous thrombosis in the evaluation of streptokinase and heparin therapy. J Lab Clin Med. 1977;89:1018-29.
18. Porter JM, Moneta GL. Reporting standards in venous disease: An update. J Vasc Surg. 1995;21:635-45.

19. Masuda EM, Kistner RL, Eklof B. Prospective study of duplex scanning for venous reflux: Comparison of Valsalva and pneumatic cuff techniques in the reverse Trendelenburg and standing positions. J Vasc Surg. 1994;20:711-720

20. Wolosker N, Nakano L, Rosoky RA, Munia MA, Muraco Netto B, Puech-Leão P. Endovascular treatment for intermittent claudication in patients who do not improve with clinical treatment. Clinics. 2005;60:193-200

21. Comerota AJ, Aldridge SC. Thrombolytic therapy for deep venous thrombosis: a clinical review. Can J Surg. 1993;36:359-64.

22. Bergqvist D, Jendteg S, Johansen L, Persson U, Odegaard K. Cost of long-term complications of deep venous thrombosis of the lower extremities: an analysis of a defined patient population in Sweden. Ann Intern Med. 1997;126:454-7.

23. Strandness DE Jr, Langlois Y, Cramer M, Randlett A, Thiele BL. Longterm sequelae of acute venous thrombosis. JAMA. 1983;250:1289-92.

24. Holm HA, Finnanger B, Hartmann A, Laerum F, Lohren O, Ruud TE, et al. Heparin treatment of deep venous thrombosis in 280 patients: symptoms related to dosage. Acta Med Scand. 1984;215:47-53.

25. Krupski WC, Bass A, Dilley RB, Bernstein EF, Otis SM. Propagation of deep venous thrombosis identified by duplex ultrasonography. J Vasc Surg. 1990;12:467-75

26. Markel A, Manzo RA, Strandness DE. The potential role of thrombolytic therapy in venous thrombosis. Arch Intern Med 1992;152:1265-7.

27. Semba CP, Dake MD. Iliofemoral deep venous thrombosis: Aggressive therapy with catheter-directed thrombolysis. Radiology. 1994;191:48794.

28. Ouriel K, Gray B, Clair DG, Olin J. Complications associated with the use of urokinase and recombinant tissue plasminogen activator for catheter directed thrombolysis peripheral arterial and venous thrombolysis. J Vasc Interv Radiol. 2000;11:295-8.

29. AbuRahma AF, Perkins SE, Wulu JT, Ng HK. Iliofemoral deep vein thrombosis: Conventional therapy versus lysis and percutaneous transluminal angioplasty and stenting. Ann Surg. 2001;233:752-60.

30. Elsharawyy M, Elzayat E. Early results of thrombolysis vs anticoagulation in iliofemoral venous thrombosis. A randomised clinical trial. Eur J Vasc Endovasc Surg. 2002;24:209-14.

31. Patel NH, Stookey KR, Ketcham DB, Cragg AH. Endovascular management of acute extensive iliofemoral deep venous thrombosis caused by May-Thurner syndrome. J Vasc Interv Radiol. 2000;11:1297302.

32. Hurst DR, Forauer AR, Bloom JR, Greenfield LJ, Wakefield TW, Williams DM. Diagnosis and endovascular treatment of iliocaval compression syndrome. J Vasc Surg. 2001;34:106-13.

33. O'Sullivan GJ, Semba CP, Bittner CA, Kee ST, Razavi MK, Sze DY, et al. Endovascular management of iliac vein compression (May-Thurner) syndrome. J Vasc Interv Radiol. 2000;11:823-36. 
34. Meissner MH, Caps MT, Zierler BK, Polissar N, Bergelin RO, Manzo RA, et al. Determinants of chronic venous disease after acute deep venous thrombosis. J Vasc Surg. 1998;28:826-33.
35. Comerota AJ, Throm RC, Mathias SD, Haughton S, Mewissen M. Catheter-directed thrombolysis for iliofemoral deep venous thrombosis improves health-related quality of life. J Vasc Surg. 2000;32:130-7. 